Article

\title{
Privileged Rebels: A Longitudinal Analysis of Distinctive Economic Traits of Catalonian Secessionism
}

\author{
Josep M. Oller ${ }^{1, *}$, Albert Satorra ${ }^{2}$ and Adolf Tobeña ${ }^{3} \mathbb{D}$ \\ 1 Department of Genetics, Microbiology and Statistics, University of Barcelona, 28008 Barcelona, Spain \\ 2 Department of Economics and Business, Universitat Pompeu Fabra, 08005 Barcelona, Spain; \\ albert.satorra@upf.edu \\ 3 Department of Psychiatry and Forensic Medicine, Institute of Neurosciences, \\ Autonomous University of Barcelona, 08193 Cerdanyola (BCN), Spain; adolf.tobena@uab.cat \\ * Correspondence: joller@ub.edu
}

Received: 7 December 2019; Accepted: 10 February 2020; Published: 15 February 2020

\begin{abstract}
During the last decade, the Catalonian secessionist challenge induced a chronic crisis within Spain's politics that does not offer hints of a viable arrangement. The rapidly escalating demands for secession ran almost in parallel with the accentuation of the economic recession that followed the disruption of the world financial system in 2008-2010. Such secession claims reached maximums during 2012-2014, attaining support levels of nearly 50\% of citizenry in favour of independence. These figures subsequently diminished a bit but remained close to that level until today. Despite the coincident course, previous studies had shown that the impact of economic hardships was not a major factor in explaining the segregation urgencies, connecting them instead to triggers related to internecine political struggles in the region: Harsh litigations that resulted in an abrupt polarization along nationalistic features in wide segments of the population. In this longitudinal analysis based on the responses of 88,538 individuals through a regular series of 45 official surveys, in the period 2006-2019, we show that economic factors did play a role in the secessionist wave. Our findings showed that the main idiomatic segmentation (Catalan vs. Spanish, as family language) interacted with economic segmentations in inducing variations on national identity feelings that resulted in erosions of the dual CatSpanish identity. Moreover, our findings also showed that the more privileged segments of Catalonian citizenry where those that mostly supported secession, whereas poorer and unprotected citizenry was clearly against it. All the data points to the conclusion that the secessionist challenge was, in fact, a rebellion of the wealthier and well-situated people.
\end{abstract}

Keywords: Catalonia; secessionism; household net income; family/mother language

\section{Introduction}

Catalonian secessionism acquired relevance in Spanish politics from 2010 onwards. Before that, social activism and political parties pursuing secession were a minor issue. Secessionist forces won three regional elections and sustained governments by tiny majorities in the Autonomous Parliament in this period. Two anomalous consultations about self-determination were organized and around 2 million (38\% of population census) supported secession from Spain. An "Independence Declaration" was proclaimed on 27 October 2017, devoid of any legal or practical consequence. Such a move resulted in the full suspension of home rule, sanctioned by Spanish Parliament, that endured until mid-2018.

Secessionist parties renovated their lead at the last regional election (27 December 2017). The Spanish Government decided to advance elections both to defuse the crises and finish the suspension of home rule. The results, however, confirmed the stagnation though the formation of a new Regional 
Government had to wait until mid-2018, after several attempts to reinstate in power the rebellious leaders who had fled to exile or been imprisoned. These unsuccessful efforts were blocked by legal provisions dictated by the Spanish High Court. A left-wing government was formed in Spain, in June 2018, which had the initial support from Catalonian and Basque nationalists. This seemed to open an opportunity to explore new arrangements but the talks between the Central Government and the secessionist Catalan government did not lead to any advancement. At Spain's general election of 28 April 2019, left-wing parties renovated their lead, although without reaching a stable majority. The formation of a new government had to wait until January 2020, after a new general election, on November 2019, that finally led to an apparently viable left coalition. On 14 October 2019, the Spanish Supreme Court ${ }^{1}$ handed down sentences of several years in prison to nine secessionist leaders, finding them guilty of sedition for their role in the failed 2017 bid for independence.

The surge of pressing demands for independence has thus endured, with minor oscillations, since 2010. Two regional elections (September 2015; December 2017), two illegal referendums of self-determination in which only the secessionists went to the poll stations (9 November 2014; 1 October 2017), and a series of systematic surveys both by CEO (the official survey agency of the Regional Government) ${ }^{2}$ and CIS (the official survey agency of the Central Government) ${ }^{3}$, showed the existence of a political division in two halves on the issue of secession. Over the last five years the question "Do you want Catalonia to be an independent state?" (CEO series of "political barometers") received $45 \%$ to $48 \%$ "YES" answers to "NO" answers from $44 \%$ to $48 \%$, and $5-10 \%$ remnants of "DON'T KNOW/NO ANSWER". Results on 21 December 2017 regional elections disclosed an almost perfectly divided society: Turnout reached an historical mark of $79.1 \%$; secessionist parties got $2,079,330$ votes $(47.33 \%)$, whereas non-secessionist parties won $2,227,421$ votes (50.71\%). A narrow margin of 150,000 votes distanced unionists from secessionists.

Catalan unionists (around three million, from a census of 5.5 million within a population of 7.5 million) did not join the secessionist venture. Most of them have familial, affective and economic links with Spain. They are heterogeneous though they predominate on coastal conurbations around Barcelona and Tarragona, as well as in other medium-sized towns (Lepic 2017; Maza et al. 2019). They remained expectant all along the secessionist surge, but during October 2017, in the weeks preceding the "Independence Declaration", unionist activism increased amid escalating tensions (Barrio and Field 2018; Garcia 2018). They deployed demonstrations in downtown Barcelona that competed with the huge ones that secessionists had mounted repeatedly (Barrio and Field 2018; Coll et al. 2018; Crameri 2014, 2015; Garcia 2018; Tobeña 2017a, 2017b).

The main social consequence of the sustained secessionist campaign has been the excavation of a deep political divide between two large fractions of Catalan citizenry, secessionists and unionists, which was absent before the precipitous demands of segregation from Spain (Amat 2015; Elliott 2018; Ucelay-da Cal 2018). The lack of a social majority behind the vigorous but failed secessionist venture opened apprehensions and frictions that were mostly unknown previously. Neighbours, colleagues and even friends and families who had shared feelings of belonging to both Catalonia and Spain (in different degrees) as a part of their attachments and values, are now divided on the issue of secession and must endure living together amid unsolved tension (Garcia 2018; Morel 2018; Coll et al. 2018; Oller et al. 2019a, 2019b).

The secessionist movement devoted, from the start, big efforts to convincing the world that it was deeply rooted on a spontaneous and widely distributed aspiration to attain sovereignty that came from all corners and social strata within Catalonian citizenry. That is, without distinctions that might suggest the operation of a political agenda biased by economic, territorial or cultural/ascendancy based

1 In Spain the "Supreme Court" is the highest judiciary level. The "Tribunal Constitucional" (High Spanish Court) is the highest instance for both legislative and judiciary litigations, equivalent to the Supreme Court in other Western countries.

2 CEO (Centre d'Estudis d'Opinió, http://ceo.gencat.cat/).

3 CIS (Centro de Investigaciones Sociológicas, http://www.cis.es/cis/opencms/ES/index.html). 
interests. It must be recognized that that kind of discourse obtained a good reception (Crameri 2014, 2015; Minder 2017; Dowling 2018; Cardenal 2020), though there were cautions signalling towards the concomitant influence of top-down mechanisms rooted on a harsh political struggle between secessionist formations to lead the region (Barrio and Field 2018; Elliott 2018).

\subsection{Antecedents}

While initial interpretations of the upsurge of Catalonian secessionism linked the appearance of the wave of social discontent to resentment over economic grievances against the Spanish state, during the extensive downturn of the 2008-2012 world financial crisis, recent analyses have discarded those interpretation. Applying different statistical methods, both (Bel et al. 2019; Romero-Vidal 2019) established the inability of important contextual factors to explain the surge and maintenance of the Catalonian secessionist push: Neither the impact of the economic crisis in 2008-2013 or the evolution of preferences for governance options within the region, along the whole period 1991-2018, were able to convincingly explain the appearance of intense and sustained demands for full sovereignty. Cohering with that, (Maza et al. 2019) multivariate analysis of voting behaviour at the last regional elections (21 December 2017), showed a clear priority of family ascendancy origins over economic factors to explain the electoral results. The authors (Cuadras-Morató and Rodon 2019) obtained fully concordant findings as well. The authors (Borrell and Llorach 2015) and others (Bosch and Espasa 2014; Sánchez Cartas 2015) had already shown that the attempts to justify the secessionist challenge as a response to the chronic maltreatment by a parasitic Spanish state acting with extractive procedures towards the Catalonian economy were devoid of substance and worked only as propaganda weapons to nourish the conflict.

In a systematic longitudinal analysis, (Oller et al. 2019a, 2019b) showed that family language/ascendancy origins and the biased influence of regional media were crucial and unavoidable factors of the ongoing division between secessionists and unionists. Those two factors influenced important realignments on both national identity feelings and support for secession. The same study offered hints about the potential relevance of economic segmentations as added factors for differential alignments. The relevance of some socioeconomic ingredients on preferences for secession was first highlighted by (Llaneras 2017) using data from CEO surveys near the crucial months of autumn 2017. Secession appealed mostly to native Catalans: It was higher among citizens born in Catalonia and with at least one parent born there, with a maximum (75\%) for those with long native ascendancy. For citizens coming from abroad or from other Spanish regions, and for those born in the region from migrant parents, secession was not attractive at all (CEO barometer July 2017). The divide depended also on incomes: Citizens with highest incomes and those who responded "we live comfortably" were the ones that backed secession. On the contrary, people with low salaries and those disclosing "many economic difficulties" were against secession. These previous but partial findings demanded further study that might reveal the influence of economic factors on fragmentation tensions that have appeared, in different parts of Europe, during the last two decades (Sorens 2005, 2008; Serrano 2013; Muñoz and Tormos 2013, 2015; Bourne 2014; Muro and Vlaskamp 2016; Piketty 2019).

\subsection{Plan of the Study}

Our main aim, in this paper, is to display a series of longitudinal findings that may shed light on the potential relevance that some economic factors played upon the surge of the fissure between Catalonian unionists and secessionists. By building upon the complete series of data from iterated official CEO polls (the Survey Agency of the Regional Government), including 85.538 respondents from 45 surveys, we will show the evolving changes along the period 2006-2019 of national identity feelings and political preferences on the issue of secession.

After displaying the differential geographical distribution of both electoral preferences and the degree of support for secession, we will explore, in detail, the role of various economic and social transitions that might have contributed to establishing the pattern of traits that currently characterize 
the division and entrenchment between secessionists and unionists. We will try to explore, afterwards, potential interactions between economic segmentations with variations of national identity feelings in the main two segments of Catalonian citizenry; those whose family language is Catalan vs. those whose family language is Spanish. This is mandatory since previous findings had established the priority of this ethnolinguistic cleavage rooted on ascendancy origins (Oller et al. 2019a, 2019b).

We expect that this longitudinal dissection of the relevance of socioeconomic ingredients upon the secessionist push in Catalonia will contribute to illuminating factors that may help not only to understand its origins and development, but to hopefully contribute as well to attenuating the more worrying consequences of such a crisis.

\section{Methods}

To display the structure of secessionist vs. unionist preferences among Catalonian citizenry we started by using the official electoral data from the last regional election (21 December 2017). The geographical distribution of the pro-secession vote was examined by adding the results of the three secessionist political parties: JxCat, ERC and CUP. We obtained a map (Figure 1) with 947 current Catalan municipalities coloured in distinctive tones: In red when the sum of the secessionist vote was greater than $50 \%$ of the municipal census and in pale pink, otherwise. Secondly, we obtained a map with the 947 current Catalan municipalities coloured in five green hues according to percentages of unionism votes on the electoral census of each municipality (Figure 2). These results are also summarized in Table 1.

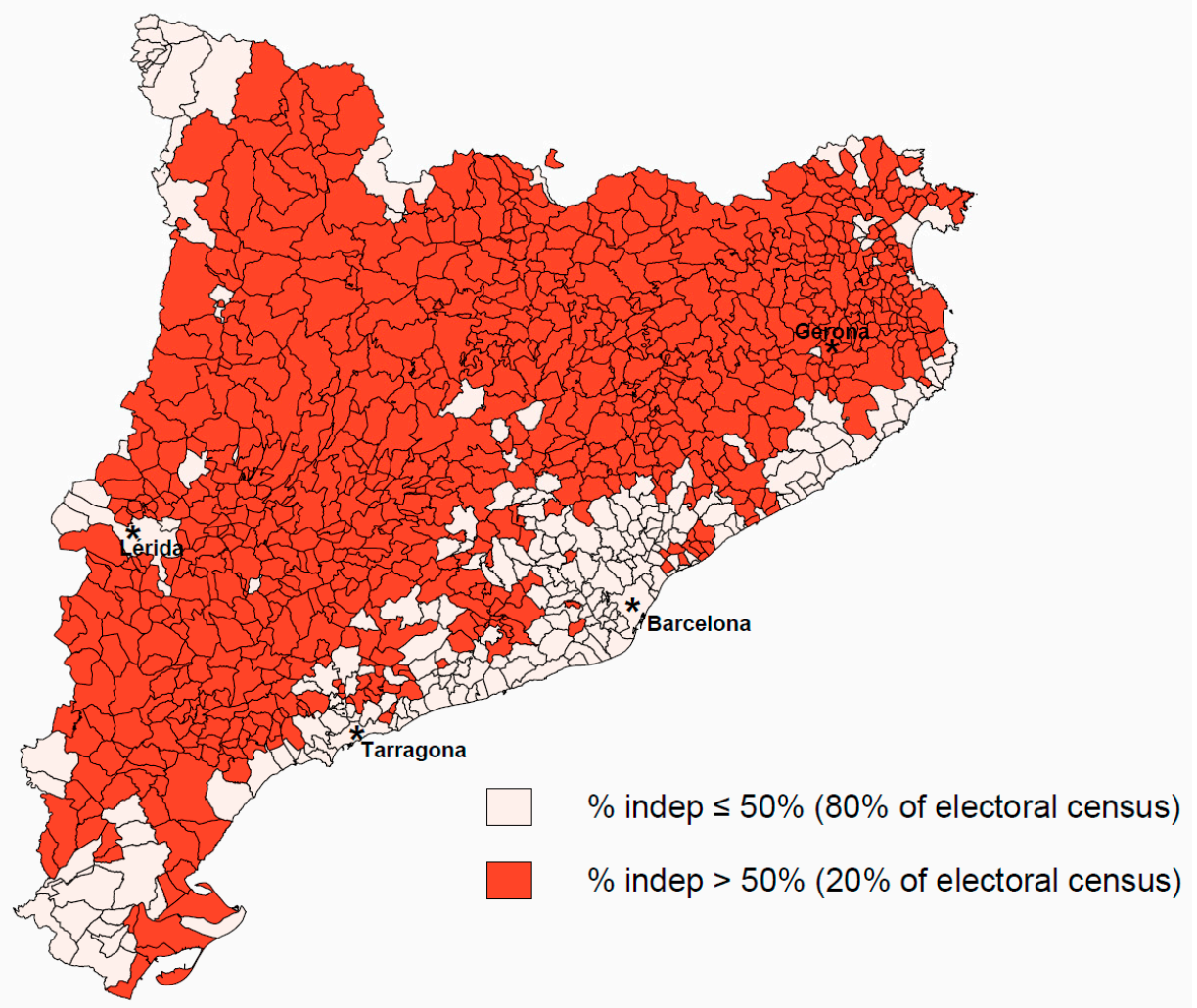

Figure 1. Geographic distribution of secessionism at regional elections 21 December 2017. The percentages by municipalities are computed over their corresponding electoral census. Secessionism is majoritarian (in red) at $76 \%$ of the municipalities, representing $78 \%$ of the surface of the whole region, but only $20 \%$ of the electoral census live in this area, while the remaining $80 \%$ live in the rest of Catalonia (in rose pale). Secessionism is concentrated at inland counties mainly, whereas unionism predominates on overpopulated coastal areas and in some Pyrenean and peripheral counties as well. 


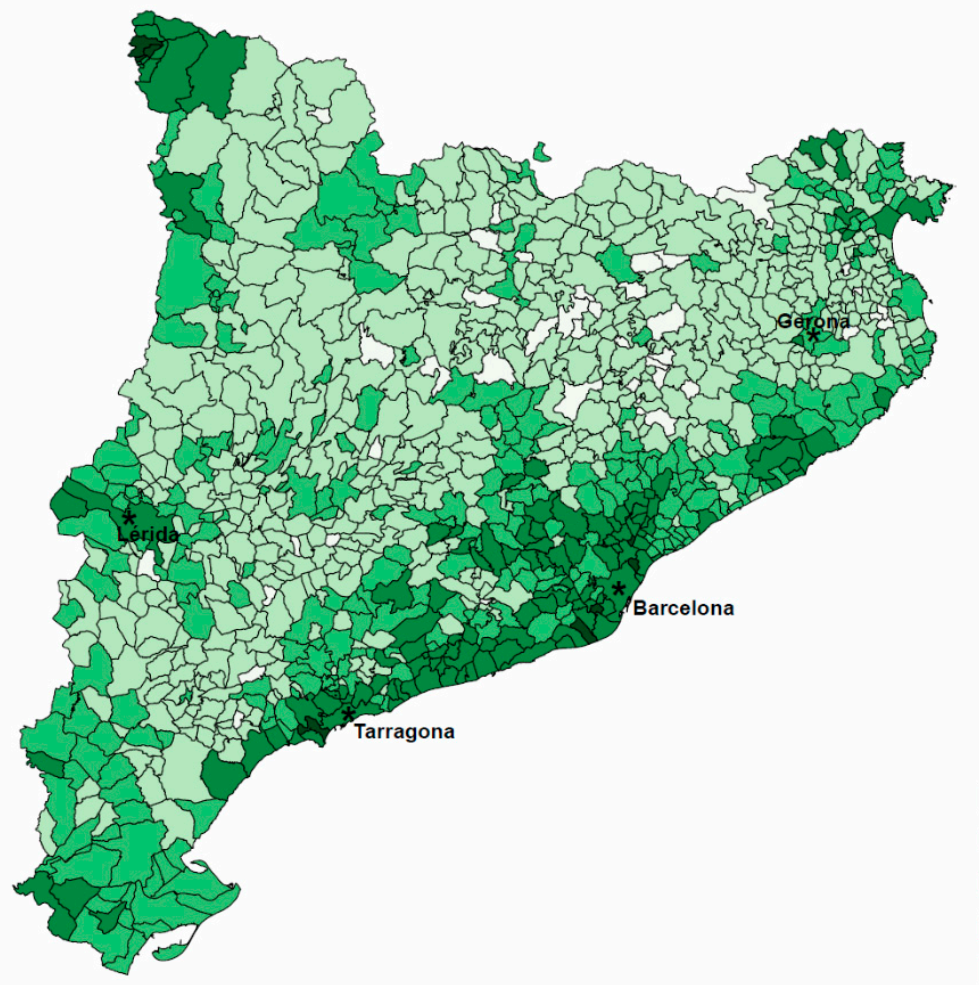

less than $20 \%$

$20 \%-40 \%$

$40 \%-60 \%$

- $60 \%-80 \%$

- more than $80 \%$

Figure 2. Geographic distribution of non-secessionist vote at regional elections 21 December 2017. The percentages by municipalities are computed over all their corresponding electoral census. The different shades of green correspond to the different percentages of unionist forces at each municipality. Observe the pattern complementary to that observed in Figure 3.

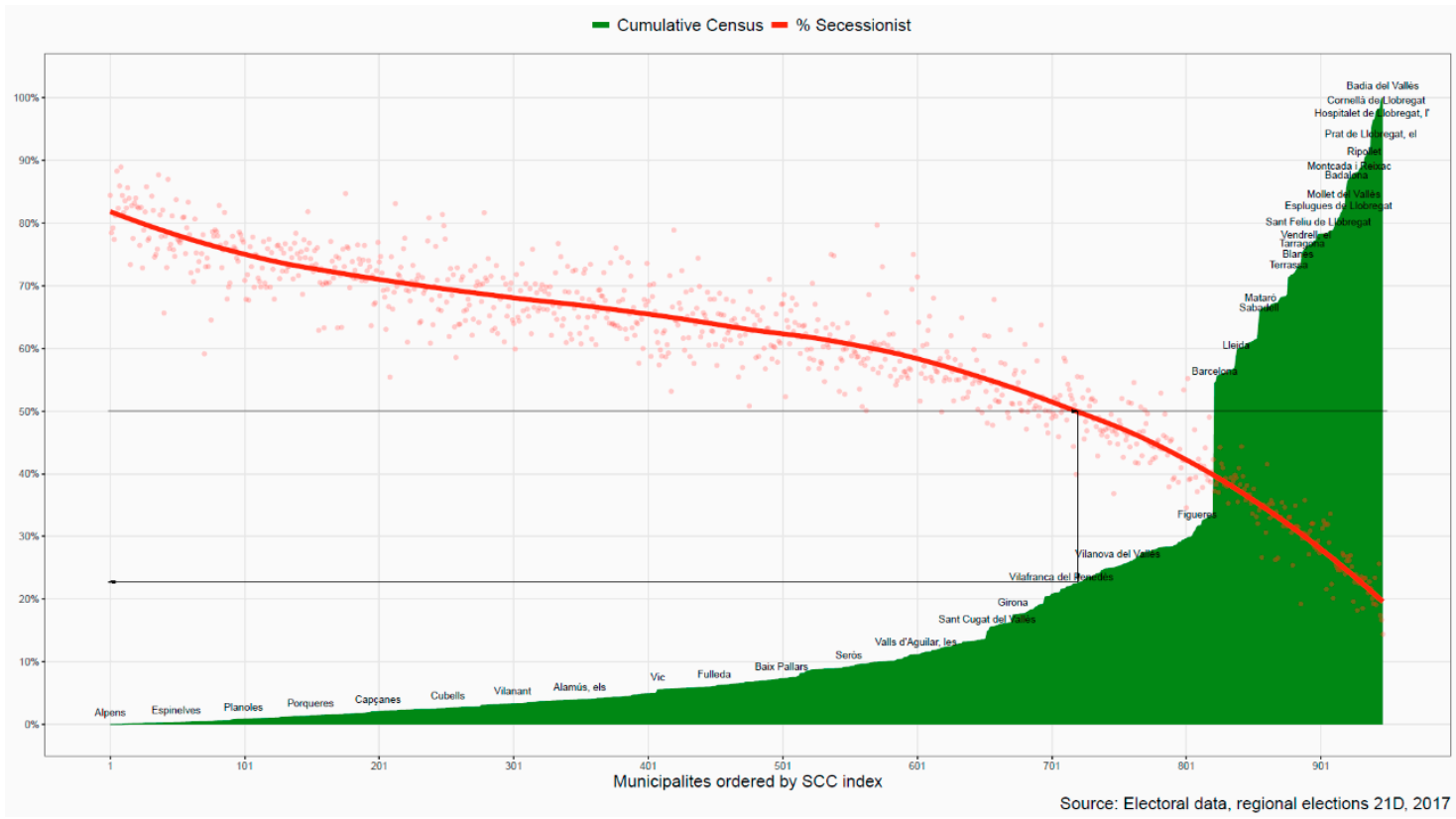

Figure 3. Catalonian municipalities sorted by the value of an index measuring "unionism" degree. This is an index based on a factor analysis over electoral data in the period 2008-2012. For each abscissa point, we show the accumulated electoral census to the left of that point, from $0 \%$ to $100 \%$ in green. We show also a smoothed average (in red) of the corresponding secessionism at each municipality. Note that the highest values appear at the smallest municipalities, while they progressively fall at the largest municipalities in the Barcelona metropolitan area. The Barcelona municipality had intermediate behavior. 
Table 1. Secessionists and non-secessionists in different geographic areas.

\begin{tabular}{ccc}
\hline & Secessionists & Non-Secessionists \\
\hline Zone in Red & $1.069 \mathrm{M}$ & $0.434 \mathrm{M}$ \\
Zone in Pale Pink & $0.996 \mathrm{M}$ & $2.829 \mathrm{M}$ \\
Total & $2.065 \mathrm{M}$ & $3.263 \mathrm{M}$ \\
\hline
\end{tabular}

We built then a way to visualize the distribution of the pro-secession vote across municipalities of the region. They were ordered according the ranks of an index obtained considering municipal, regional and general election results in the period 2008-2012 and a factorial analysis. Such an index can be interpreted as a measure of "unionism". Then we plotted simultaneously the cumulative electoral census, from $0 \%$ to $100 \%$ and a smooth moving average of percentages of secession support at each municipality (Figure 3). The shape of both plots shows the relationship between municipality sizes and support for secession. Further details could be supplied by the authors to any interested reader.

We then proceeded to analyze the evolution of several measures obtained by consecutive CEO barometers (the official survey agency of the Regional Government), during the period 2006-2019, from representative samples of Catalonian citizenry through personal interviews. Sample sizes for each survey oscillated between 2500 and 1500 citizens, with the exception of autumn 2017, which had only 1338 citizens. This longitudinal analysis was based on responses of 88,538 individuals through a regular series of 45 official surveys, in the period 2006-2019. Our variables came from particular questions on these CEO barometers. Specifically, our main economic variable was "household net incomes" for the whole population and its interaction with the main family/mother language segments (Catalan vs. Spanish). We estimated medians of "household net incomes" of segments defined by the second one. We also used a binary variable "household net incomes $\geq 3000 € / \mathrm{month}^{\prime}$ ", with two possible results "Yes" or "No", discarding the relatively few answers "do not know" or "do not answer" ("DK/NA"). We also used the qualitative variables "economic resistance limit in case of economic breakdown" (based on questions asked in two surveys in 2016 and 2017), and "perception of own economy last year", both in combination with support for secession in a (hypothetical) referendum of self-determination (as is specifically asked in these CEO barometers, but only from 2015 onwards).

\section{Longitudinal Variations on National Identity Feelings Depending on "Household Net Incomes" and Linguistic Segments}

We focused our analyses on the evolution of national identity (sense of belonging feelings) because these CEO barometers maintained a specific question on this issue, without changes, along the whole period. It had six options: "only Catalan", "more Catalan than Spanish", "as Catalan as Spanish", "more Spanish than Catalan", "only Spanish", and DK/NA. Previous work had established substantial covariation between national identity feelings and preferences in favour of or against secession, despite addressing different features (Oller et al. 2019a, 2019b). We considered the variable family/mother language and the dichotomous variable net income plus. First, we plotted the evolution of the national identity "only Catalan" on the four groups obtained crossing the main two segments of family/mother language (Catalan vs. Spanish) with the dichotomous variable net income plus (with also two levels, according to whether the household net incomes were greater than, equal to, or less than $3000 € /$ month). The graphics allowed comparisons of different evolution for these groups. Secondly, we obtained the same graphs for the national identity "as Catalan as Spanish" on the same groups, and finally we did the same with the national identity "only Spanish".

We additionally analysed this data, just as an approximation, through the perspective of Analysis of Covariance (ANCOVA). For the sake of simplicity, we started with two ordinary univariate analyses and continued with a combination of them in a trivariate version of MANCOVA that we shall describe hereafter. At the start, we considered two factors for both analyses the levels of which were the possible values of the qualitative variable family/mother language (with two levels corresponding to the main linguistic segments, Catalan and Spanish) and the dichotomous variable net income plus (according 
to whether the household net income was greater than, equal to, or less than $3000 € /$ month), using time (from 2006) as a covariate and considering as a dependent variable the percentages of those who self-identified as "only Catalan", for the first analysis, "as Catalan as Spanish", for the second one, and "only Spanish" for the third one. Since the interactions between factors were highly significant, to facilitate the analysis we built a new factor, group, with four levels, combining the two levels of family/mother language factor and both levels of the factor net income plus. We used this factor to replace the previously mentioned original binary factors at the final analysis.

Notice that there were two sources of randomness: One corresponding to the sample procedure and another corresponding to the political and communicative events throughout the period: We used a linear model as a simple way to deal with both sources of variability, just as an approximation, introducing time (in years, from 2006) to try to capture potential trends and checking the global adequacy of this approach examining the standard output supplied by the function $\operatorname{lm}$ of $\mathrm{R}$ package statistics. We supply also a graphic plot illustrating the dependence of each percentage ("only Catalan" and "as Catalan as Spanish"), with respect to the time covariate, in each one of the four levels determined by both factors.

As a final remark, in most of the plots, we marked relevant historical events that might have been crucial to understanding the evolution of the variables along the period. These events were: The date when a new home rule was approved (New Statute 2006); the resolution of the Spanish High Court (Tribunal Constitutional-TC) that sanctioned 14 articles (over 223) as contrary to the Spanish constitution and restricted the preamble and another 27 articles (June 2010); the peak protests of the social 15M movement (15M Peak Protests, June 2011); the regional elections of 25 November 2012 (25N); the illegal consultation about independence of 9 November $2014(9 \mathrm{~N})$; the regional elections of 27 September 2015, (27S); the illegal referendum about secession, 1 October 2017 (1 Oct) and the regional elections 21 December 2017 (21D).

We were fully aware of the limits and restrictions we adopted in our analyses of an obviously multi-causal phenomenon. We limited ourselves to studying significant stochastic dependencies between variables, a strictly statistical work (descriptive plus correlational), although it is true that, in this context, high stochastic associations might suggest plausible explanations, of at least part of the mechanisms that shaped the observed trends.

\section{Results}

We started by geographically localizing the relevance of support for secession using the official results of the last regional elections (21 December 2017), and adding the votes obtained by the three main current secessionist parties: JxCat (right), ERC (left) and the CUP (far left). These regional elections are the event where secessionist support is more clearly revealed, as majorities at the Autonomous Parliament and the Government depend on them.

As in Figure 1, when secession support at each municipality was greater than $50 \%$ of the electoral census, they were indicated in red. The highest values were found at the smallest municipalities, while they progressively dropped at the largest municipalities of Barcelona and Tarragona conurbations. Barcelona city showed intermediate scores. The main trend is exemplified with the following two results: Santa Cecília de Voltregà: Electoral census 163 citizens, secession support: 89.0\%; Badía del Vallés: Electoral census 10,560 citizens, secession support: 14.5\%. Figure 2 presents an image complementary to the previous one, showing percentages of support for unionist forces at each municipality with different shades of green.

The summary of the results for Figures 1 and 2 appears in Table 1 (from the electoral data of 21-12-2017, the last regional elections):

Secessionists are majoritarian in three quarters of the territory, but less than $25 \%$ of the electoral census live in those parts of the region, while in the remaining part, more than $75 \%$ of the census is concentrated. 
We developed also an alternative method to visualize the differential distribution of the pro-secession vote, presented in Figure 3. The municipalities are ordered in terms of an index, developed from a factorial analysis obtained from electoral data in general and regional elections throughout the period 2008-2012. This index, which shall be referred to hereafter as the unionism index, measures the degree of support for unionist forces at each municipality, from low to high degrees. The accumulated census and percentages of support for secessionist forces are represented for each municipality. The percentage of secession support is represented through a smooth curve, based on moving averages.

\subsection{Longitudinal Changes of Household Net Incomes on the Main Family Language Segments}

Based on Household net income levels among citizens with family/mother language Catalan and those with family/mother language Spanish, we estimated the medians of household net incomes for each linguistic segment throughout the period 2006-20194. Citizens with family language Catalan exhibited higher household incomes throughout the entire period compared with citizens with family language Spanish. The trend line suggests that the economic crisis increased the magnitude of such inequality (Figure 4).

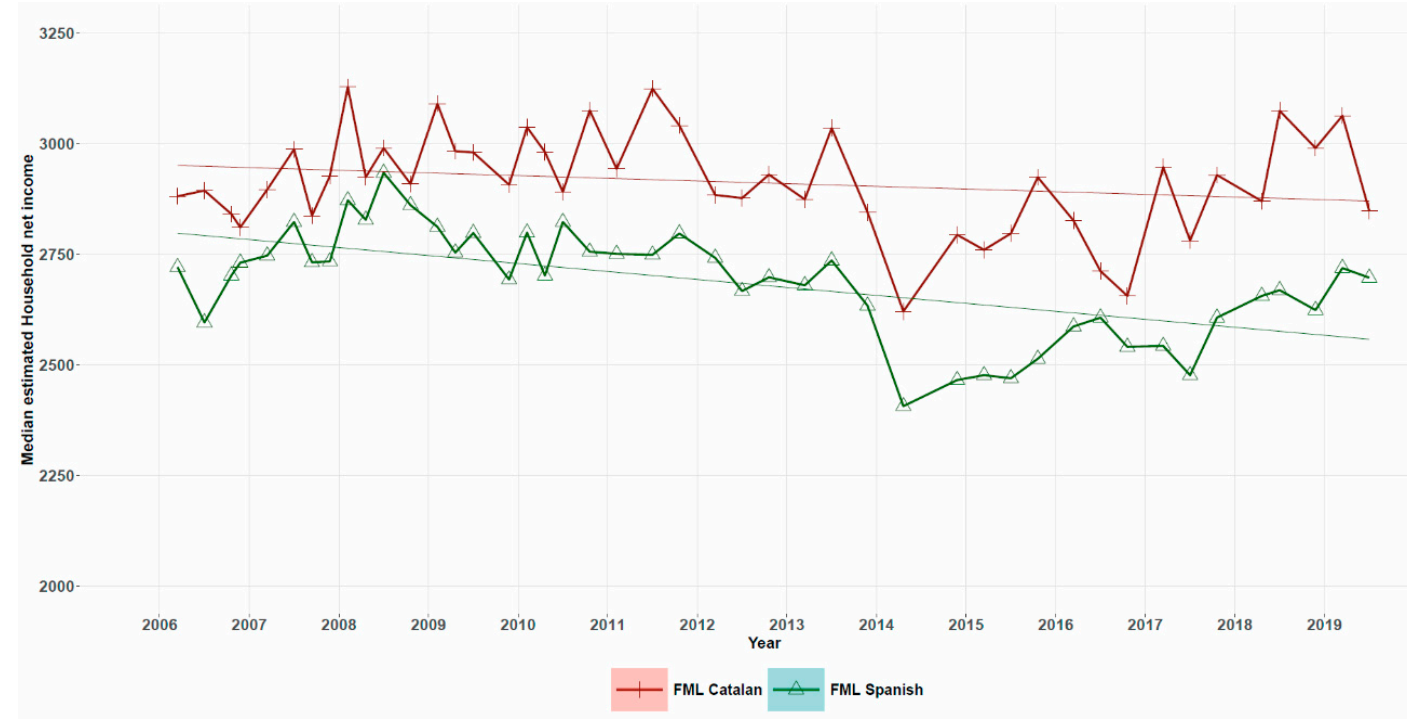

Figure 4. Evolution of median estimates of household net incomes among citizens with family/mother language Catalan vs. those with family/mother language Spanish. Observe the differences between these groups and how they increase along the economic crisis. Primary source: CEO barometers 2006-2019. FML: Family/mother language (FML Spanish: 56\% of Catalonian citizenry; FML Catalan: 36\%; FML both Catalan and Spanish 6\%; source: EULP2018-Enquesta Usos lingüístics de la població, Institut Estadístic Catalunya; https://www.idescat.cat/pub/?id=eulp).

Figure 5 displays the percentages of "Yes" in a (hypothetical) referendum of self-determination in population segments determined by family/mother language and the binary variable "household net incomes $\geq 3000 € /$ month" with two values "high" (greater than $3000 € /$ month) or "low" (lower than $3000 € /$ month). The difference between these idiomatic segments was huge throughout the 2015-2019 period. There were also differences depending on income: Wealthier respondents were more in favour

4 Until summer 2011 the survey question explicitly asked for 'family language', and after that for 'childhood language in the family'. This change resulted in a decrease in the percentage of people who answered 'both languages' and an increase in the Spanish-mother language segment, but it did not significantly affect other variables within the surveys immediately before and after that change. 
of secession in both idiomatic segments. Finally, a slight tendency to increase support of secession appeared among Spanish speaking citizens with lower incomes.

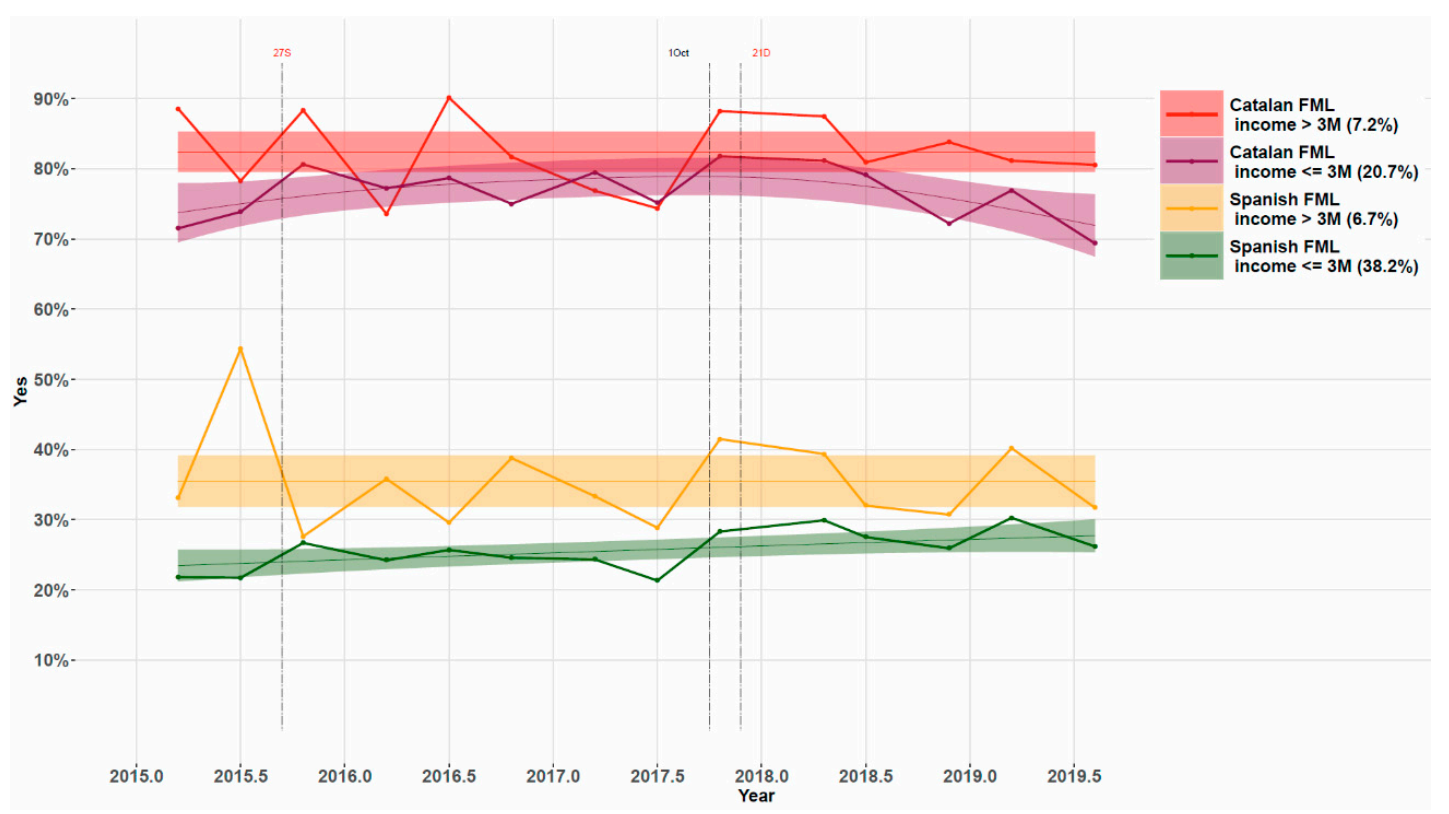

Figure 5. Covariation between household net incomes and family/mother language segments on support for secession in a (hypothetical) referendum of self-determination. Attached to each label comes respondent percentages, for each segment, at a July 2019 CEO survey; rests up to $100 \%$ were DK/NA responses. $1 \mathrm{M}=$ one thousand euros/month. FML: Family/mother language.

3.2. Longitudinal Variations on National Identity Feelings by Household Net Incomes and Family/Mother Language Segments

To obtain a more detailed picture of the potential relevance of economic variables in influencing the division between secessionism and unionism we analysed the evolution of "national identity" feelings in the main two linguistic segments taking into account the variable "household net incomes $\geq$ $3000 € /$ month", with two values "high" (greater than $3000 € /$ months) or "low" (lower than $3000 € /$ month). First, we directed focus (Figure 6) to the national identity "only Catalan" for Catalan speakers (as defined by family/mother language) and for Spanish speakers (also defined by family/mother language).

In both idiomatic segments, wealthier strata moved towards an increase on the national identity "only Catalan", although the jump was much more substantial on the fraction that had Catalan as family language. Observe the distance between the biggest group, family/mother language Spanish, with household net income not greater than $3000 € /$ month, in green $(38.2 \%$ of respondents, at that survey), and the family/mother language Catalan group with household net income greater than $3000 € /$ month $(7.2 \%$ of respondents, at that survey), in red. Notice also that trend lines overlap or almost overlap at the beginning of the period and we may conjecture that Catalan subgroups (red and purple) should have had similar figures in the recent past, around the start of the present century. The sizes of the purple and orange subgroups were $20.7 \%$ and $6.7 \%$, respectively, at the last survey. 


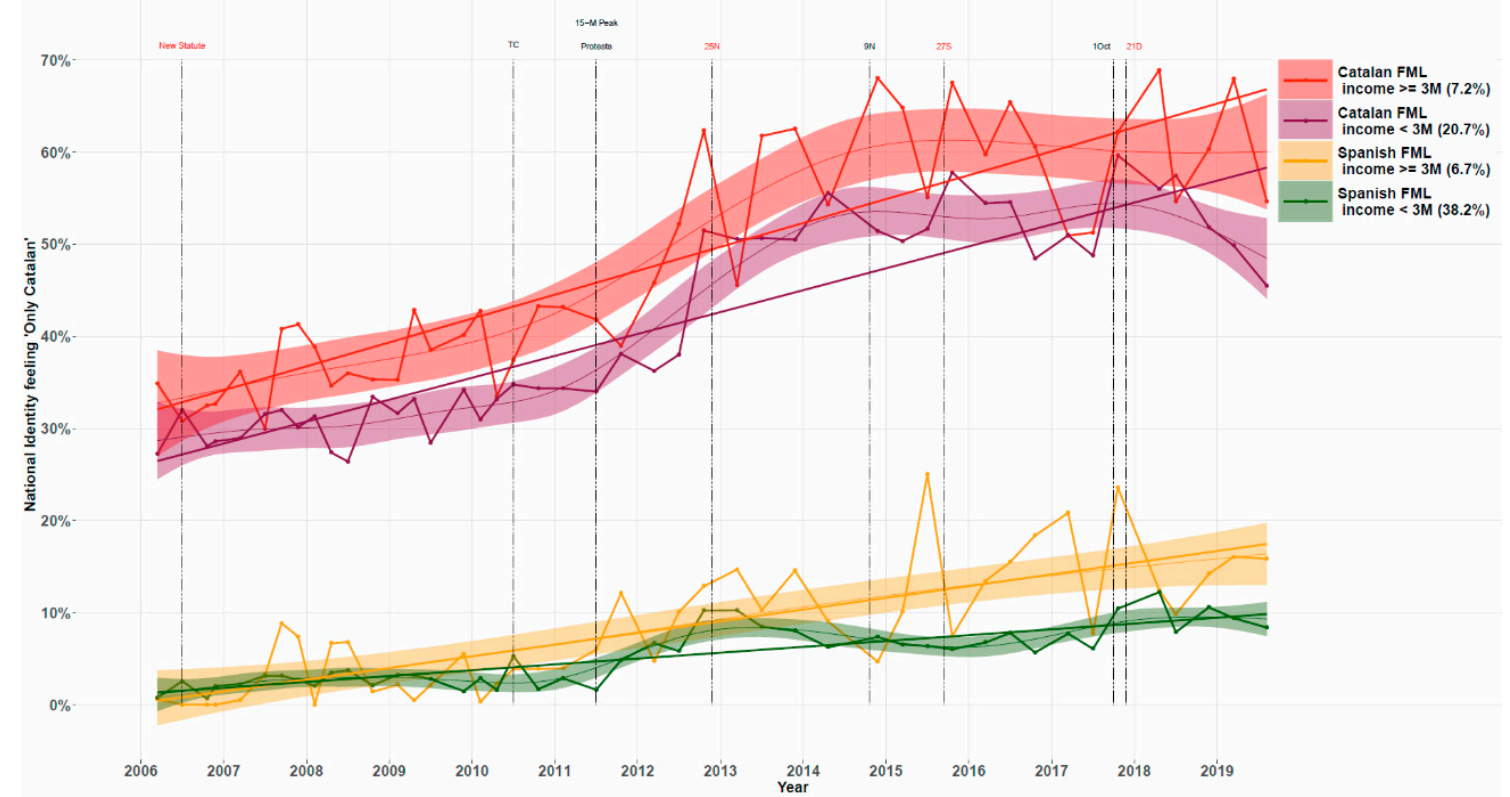

Figure 6. Evolution of "only Catalan" national identity depending on family/mother language and household net income (2006-2019). The size of this identification type went from $14.2 \%$ of the entire Catalonian population in a March 2006 survey, up to 23.5\% in July 2019. Attached to each label are size percentages, for each group, at a July CEO 2019 survey. FML: Family/mother language.

These abrupt variations on the national identity "only Catalan" were clearly dependent on family language and on household net incomes $\geq 3000 € /$ month. Their respective relevance was examined through a standard analysis of covariance. The dependent variables were percentages of "only Catalan" national identity, considering a factor group (four levels), and time (year) as a covariate, with an adjusted R-squared of 0.95282 with a very significant global $p$-value $<2.2 \times 10^{-16}$. The group factor and the interactions were highly significant $\left(p\right.$-values $\left.<1.282 \times 10^{-15}\right)$. Furthermore, comparing the slopes of the regression lines, we found that almost all contrasts showed highly significant differences (p-value, obtained by the Tukey method, were equal to 0.0001), with the exception of the slopes among lines within family/mother language Catalan (p-value, 0.8051). Contrasts between lines within family/mother language Spanish groups were slightly significantly different ( $p$-value, 0.0425$)$. Other results from this analysis were also obtained and can be supplied by the authors to the interested readers on demand

We repeated the same approach to the national identity "as Catalan as Spanish" (Figure 7). Variations were smaller and there was a big degree of overlap at the start of the period in Spanish speaking segments. The same analysis of covariance was repeated considering the percentages of the "as Catalan as Spanish" national identity as a dependent variable, with the same factor group and time as covariates, as before, with an adjusted R-squared of 0.9397 with a very significant global $p$-value $<2.2$ $\times 10^{-16}$. The effects of group factor and the interactions were highly significant. Moreover, comparing the slope of the regression lines, only those within family/mother language Spanish were significantly different ( $p$-value obtained by Tukey method were equal to 0.0003 ). The slopes of household net incomes greater than $3000 € /$ month segments, comparing family/mother language Catalan versus the corresponding Spanish were also different ( $p$-values obtained by Tukey method, equal to 0.009). Other results from this analysis were also obtained and can be supplied by the authors to interested readers on demand. 


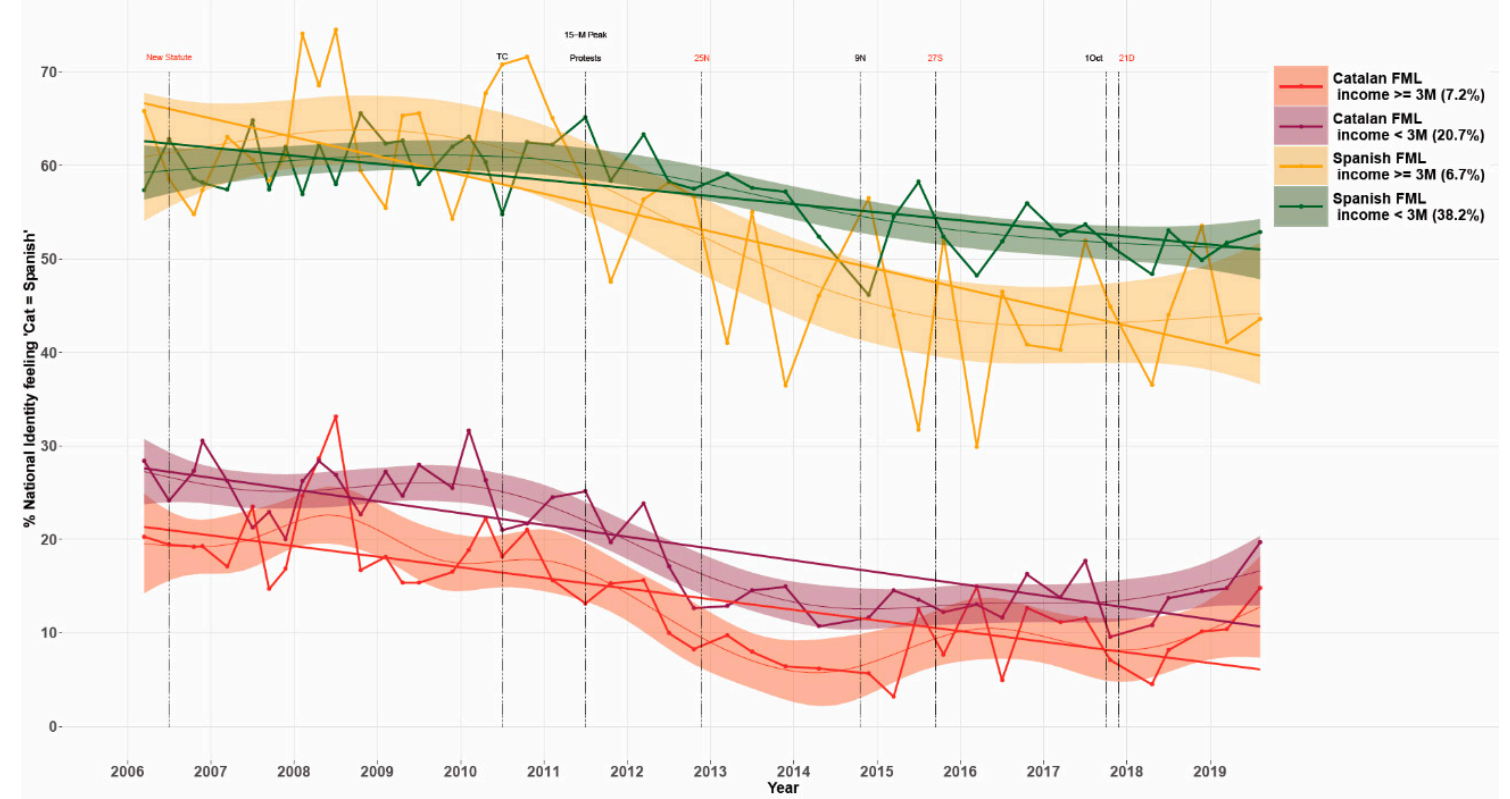

Figure 7. Evolution of "as Catalan as Spanish" national identity depending on family/mother language and household net income (2006-2019). The size of this identification type went from $42.5 \%$ at a March 2006 survey, to $39.2 \%$ in July 2019. Attached to each label are size percentages, for each group, at a July CEO 2019 survey. FML: Family/mother language.

The same analysis of covariance was finally applied to the percentages of "only Spanish" national identity as dependent variable (Figure 8), with the same factor group and time as covariates, as before, with an adjusted R-squared of 0.7906 , a worse model fit than the previous cases, but still with a very significant global $p$-value $<2.2 \times 10^{-16}$. The effects of group factor and the interactions were highly significant. In this case most of the comparisons between the slopes of regression lines were not significantly different, with the exception of the contrast between family language Catalan-household net income greater or equal $3000 € /$ month compared with family language Spanish-household net income less than $3000 € /$ month (p-values obtained by Tukey equal to 0.0284). Observe in Figure 8 that wealthier households of Spanish language had less polarized national identity (only Spanish), just the opposite of the wealthier Catalan family language segment. Observe also that scores for national identity "only Spanish" attained total levels that were 15 percent lower than those of national identity "only Catalan". The apparently large oscillations in the figure are due to the tiny sizes of subgroups of "only Spanish" national identity. 


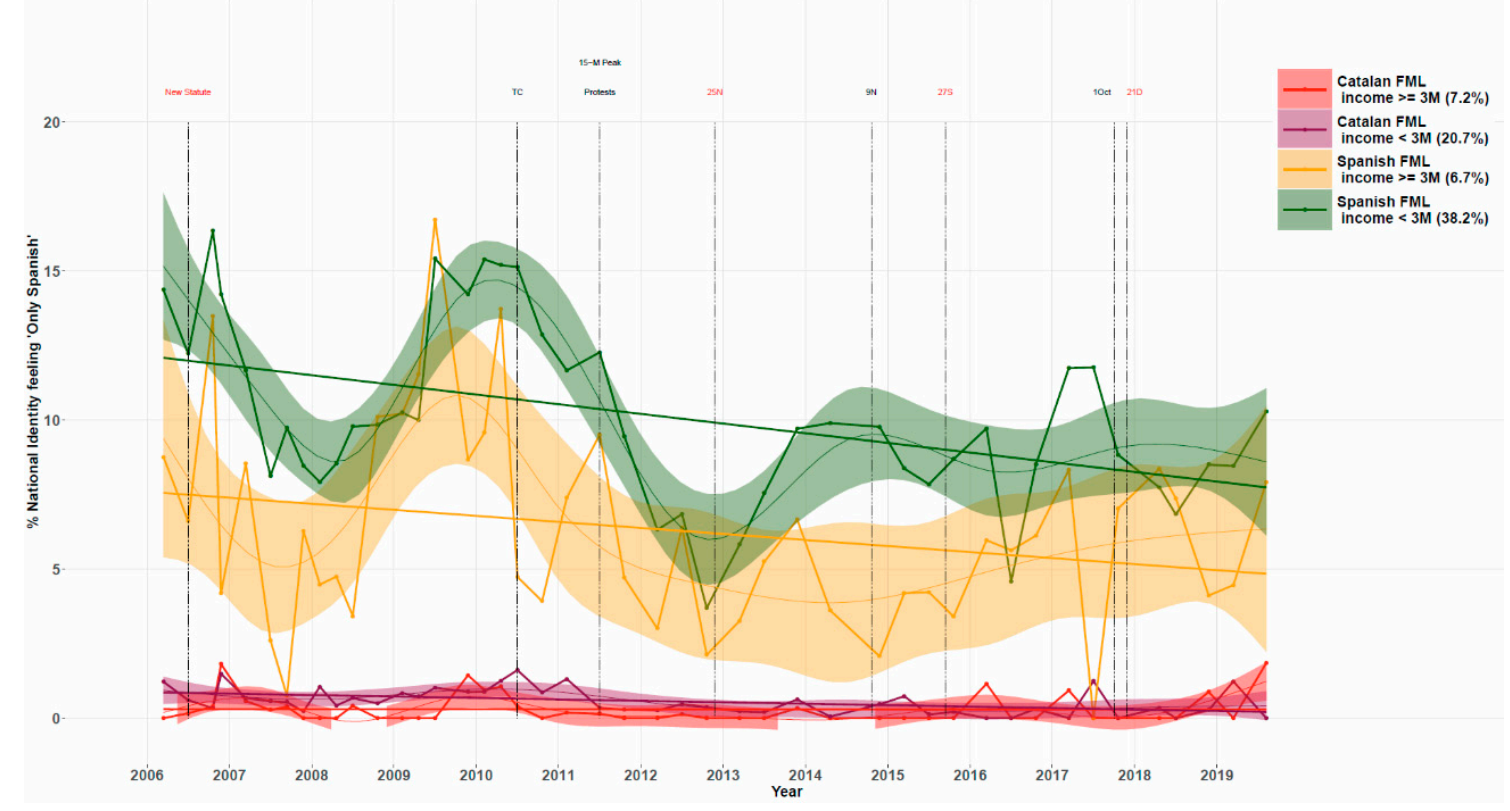

Figure 8. Evolution of "only Spanish" national identity depending on family language and Household net income (2006-2019). The size of this identification was pretty stable across the whole period, with levels between 6\% and 7\%. Attached to each label re size percentages, for each group, at a July 2019 survey. FML: Family/mother language.

To complete the analysis, we considered both dependent variables simultaneously (MANCOVA), obtaining that group factor, the covariate Time and the interactions were highly significant. Again, other standard results for this analysis were obtained and can be supplied by the authors to interested readers on demand.

\subsection{Other Economic Measures}

Finally, we compared the degree of secession support among different groups obtained considering their reported economic resistance limits (in months), in case of an economic breakdown (Figure 9). Results showed that secessionism significantly increased with higher economic resistance and endurance: People with higher financial resources were much more in favour of secession. A very similar trend appeared when the measure was perception of the own economy during last year. When that perception improved, support for secession was higher as well. In all, these findings consistently indicated that the recent secessionist wave in Catalonia has been sustained by those society segments that enjoy better economic resources and higher well-being. 
Resistance limits (in months), in case of an economic breakdown (2016-2017)

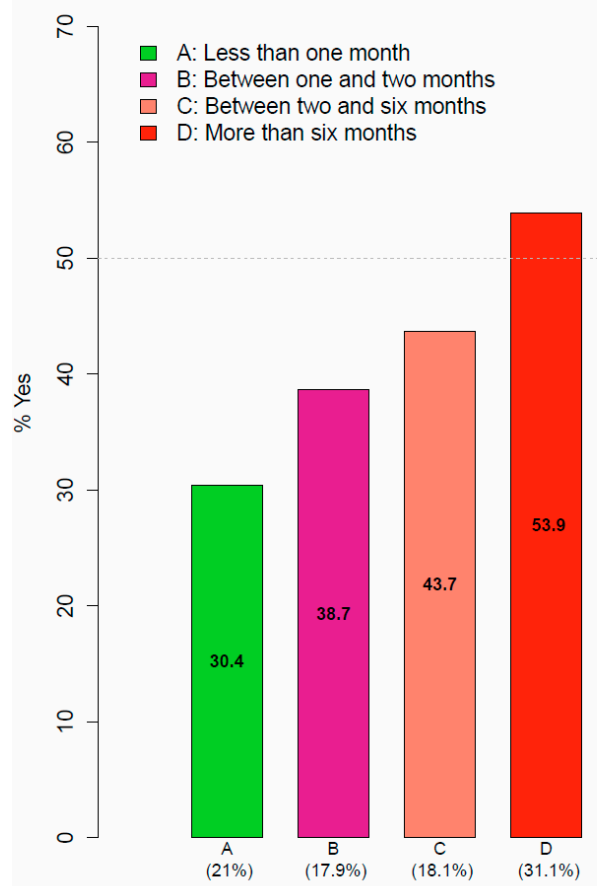

\section{Perceptions of personal economic conditions compared with previous year (July 2019)}

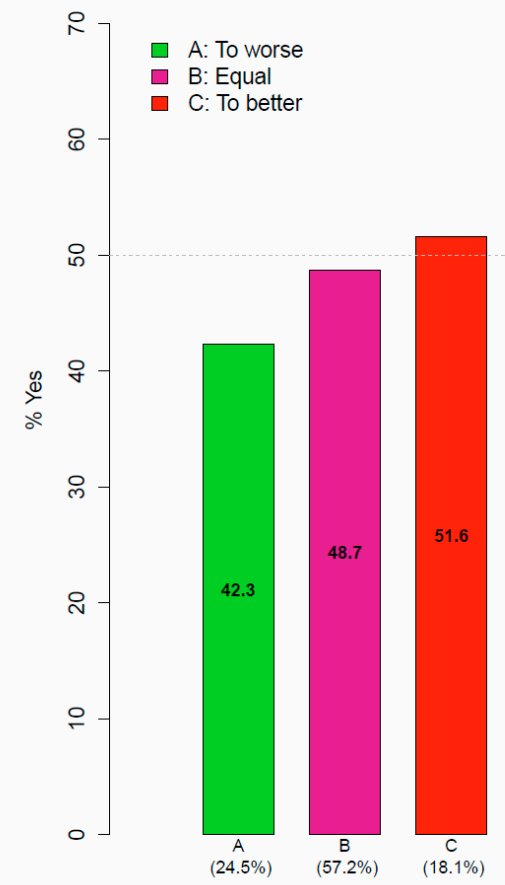

Figure 9. Support for secession and Economic wellbeing. Left: Secession was much more popular among those with higher economic resistance limits (in months), in case of an economic breakdown. Percentages are means from CEO barometers 2016-2017. Right: It was also more popular among those with a good perception of the evolution of their economies during the last year. Percentages derived from CEO barometer July 2019.

\section{Discussion}

The present study adds important findings to the recent longitudinal description of crucial vectors characterizing the division of Catalonian society into two confronted communities, unionists and secessionists, through the eruption of an unexpected and mostly not yet fully explained secession crisis within a rich and advanced region of Southern Europe (Oller et al. 2019a, 2019b).

Figures 1 and 2 offer a useful complement to our main longitudinal portrait by showing maps of the geographical distribution of support to secessionist and unionist forces using recent electoral results. They display that heavily populated coastal areas of Catalonia were less enthusiastic about secession. This was also reflected on the score (y-axis value) of the unionism index (Figure 3), where large municipalities correspond mainly to towns situated on the coastal conurbations of the region. These big conurbations have the highest proportions of citizens from migrant origins, either from other Spanish regions or from abroad (Barceló 2014; Guntermann et al. 2018; Hierro 2015; Lepic 2017; OEC Group 2017; Rodon and Guinjoan 2018).

The economic findings presented here offer a systematic scenario. Figure 4 shows that there was a persistent difference of family incomes between the two main segments of Catalonian citizenry, those whose family language is Catalan vs. those whose family language is Spanish; the former enjoying a higher median income across all the period. The income of both groups fluctuated with the development of the lengthy repercussions of the 2008 financial crises, but the distance of incomes between both groups persisted and even tended to increase throughout the period. Figure 5 shows the evolution of percentages of support for secession in a (hypothetical) referendum of self-determination differentiating two levels of income (above and below 3000 euros) and combining that with family/mother language segmentation, Catalan vs. Spanish. The graph illustrates that, regardless of their level of income, citizenry with family/mother language Catalan gave substantially more support to secession than the 
Spanish language segment. The difference was so large that it appears to reveal that the sharp division on the preference for secession depends mainly on an ethnolinguistic cleavage.

Results displayed at Figures 6-8 present longitudinal analyses of variations on different national identity feelings throughout the whole period 2006-2019. Figure 6 focuses on the evolution of national identity feeling "only Catalan" differentiating between the abovementioned two levels of income. The escalation of the identity feeling "only Catalan" was maximum for the wealthier segment of those with family/mother language Catalan. At the start of the period, however, there were no distinctions on that restrictive national identity within such a Catalan speaking citizenry segment. For citizens with family/mother language Spanish, there was also a very slight trend of increasing "only Catalan" identity, and again the wealthier ones taking the same lead, though a bit later. Figure 7 displays the evolution of differences on the national identity "as Catalan as Spanish" using the same type of segmentations. There was an erosion of this dual identity on both citizenry idiomatic segments, with the erosion being higher for the wealthier subgroups. To be noted is that, for the wealthier pertaining to the family/mother language Spanish group, the erosion of this dual identity was more intense, whereas the poorer remained more stable. Figure 8 displays the variations on national identity "only Spanish" within both citizenry lingustic segments differentiating again for levels of income, though these were very thin strata (low percentages) within the population. For the family/mother language Catalan fraction there was no variation at all, as percentages of that identity for this citizenry segment were close to zero. The family/mother language Spanish segment presented large fluctuations which were likely due to the very small sizes.

Finally, Figure 9 introduced two subjective measures of economic resistance/endurance and perception of current personal economic situation. Two findings were relevant: One, that the intensity of support for secession varied significantly with these measures (the degree of secession support aligning positively and strikingly with both measures); and, second, support for secession attained maximums when economic resistance was stronger and economic perception was clearly optimistic. In all, these results cohere with previous (partial) findings reported by other authors on the relation between secession support and economic wellbeing (Llaneras 2017; Coll et al. 2018; Piketty 2019) and extend their relevance by showing consistent differences across the whole period of the secessionist campaign. They also unveiled suggestive co-variations between the main ethno-linguistic cleavage at the region and economic segmentations, but gave more relevance to the idiomatic than to economic distinctions.

Before the dawn of the secessionist surge, (Boylan 2015) had already shown using CEO surveys 2011-2013, that national identity (being Catalan native or assimilated) was a much better predictor of desire for secession, than perceived grievances coming from an unfair fiscal treatment or other economic-political factors. Cohering with that, (Miley 2007) established the operation of divergent modes of national identification across the main segments of Catalonian society that rested on an ethno-cultural gap. Departing from CIS $^{5}$ surveys and other social data, he challenged the depiction of Catalonian nationalism as a form of "civic nationalism". He described a cleavage that distinguished the self-identification of two citizenry segments: "Native, Catalan speaking" citizens and their Spanish-speaking neighbours with immigrant origins from other regions of Spain. "Mother tongue" had, in fact, the strongest impact upon identity feelings as predominantly Catalan vs. mostly Spanish or mixed "CatSpanish". In subsequent studies, (Miley 2013) showed that there was also a gap between political preferences of these citizenry segments and those implemented by their representatives in the Regional Parliament: Language and education policies, particularly, were inconsistent with preferences of Spanish-speaking citizens. He identified, moreover, two mechanisms that blocked their representation in the region's institutions: (1) A clear under-representation of those citizens within Parliament; and (2) a partial assimilation of some Spanish-speaking politicians into the attitudes of

CIS (Centro de Investigaciones Sociológicas, http://www.cis.es/cis/opencms/ES/index.html). 
Catalan-speaking rulers. He concluded that the social bases of support for Catalan nationalism were "overwhelmingly ethnic" and that the movement was an elite-led, "top down" project.

The present findings add likelihood to that depiction, since we were able to show that ethno-linguistic distinctions were more powerful than economic segmentations in describing variations on both national identity feelings and polarized profiles on the issue of secession, across the entire period of the secessionist campaign. In previous though partial and transversal studies, (Barceló 2014) had already shown that idiomatic and neighbourhood contexts were crucial to keeping distinctive national identity boundaries in Catalonia, and (Hierro 2015) showed that both parents' identities and neighbourhood composition were able to counteract the effects of compulsory schooling, mainly or exclusively in Catalan language, at inducing changes in national identities in Catalonia.

The author (Piketty 2019) recently discussed data on Catalonian economic segmentations in relation to preferences in favour of, or against secession, which are also fully coincident with the present longitudinal findings. After contrasting findings obtained from different rent strata or educational levels, he concluded that Catalonian claims for secession should be conceived as a form of "fiscal egoism" born within a rich European region. A phenomenon, by the way, that he and others suggest might appear as well on a variety of segregation tensions that have erupted in other countries, within the European Union (Bourne 2014; Griffiths et al. 2015; Muro and Vlaskamp 2016; Miley and Garvía 2019; Piketty 2019).

\section{Conclusions}

To recapitulate, our findings show that the more privileged segments of Catalonian citizenry were those that supported secession more consistently, using different economic measures. They also show that these segments abruptly aligned their national identity towards the exclusive feeling "only Catalan", with high intensity and departing from recognizable points during the secessionist push. That trend was particularly important in the citizenry fraction that uses Catalan as their family language. On the other hand, poorer, fragile, and less protected Catalonian citizenry (using Spanish, mainly, as their family language) was mostly against secession. They presented also less polarized profiles or abrupt variations on national identity measures. All the data points to the conclusion that the Catalonian secessionist challenge was, in fact, a rebellion of the rich, well-situated, and predominantly well-protected people.

Author Contributions: Conceptualization, J.M.O., A.S. and A.T.; methodology, J.M.O., A.S. and A.T.; software, J.M.O. and A.S.; validation, J.M.O. and A.S.; formal analysis, J.M.O. and A.S.; investigation, J.M.O., A.S. and A.T.; resources, J.M.O., A.S. and A.T.; data curation, J.M.O. and A.S.; writing - original draft preparation, A.T. and J.O.; writing-review and editing, A.T.; visualization, J.M.O.; funding acquisition A.T. All authors have read and agreed to the published version of the manuscript.

Funding: This research was partially funded by AFOSR-MINERVA FA9550-18-0496 Grant and Bial Foundation Grant 163/14, to sustain AT work.

Conflicts of Interest: The authors declare that they have no conflicts of interest.

Ethical Statements: The data for this research came from the CEO barometers, the official survey agency of the Regional Government. Full legal Spanish requirements and restrictions to conduct studies about voting and political opinion were complied, in accordance also with ESOMAR Int. Code on Market, Opinion and Social Research and Data Analytics. All the statistical analyses fulfilled conditions established by the Ethical Commissions of the University of Barcelona, Pompeu Fabra University and the Autonomous University of Barcelona for treatment of human data, when their source are surveys made by official agencies or private firms under specific external regulations with due guarantees. An ethics approval was not required for this secondary analysis of the data, as per the authors' Institutions and national regulations.

Data Availability: As already stated the primary data is public and easily accesible at CEO web (Centre d'Estudis d'Opinió, http://ceo.gencat.cat/). In addition to the data provided here, many other analytical and graphic results were obtained for the period 2006-2019. In particular, all series of mosaic plots derived by crossing different pairs of variables. All of them can be supplied by the authors to interested readers on demand. 


\section{References}

Amat, Jordi. 2015. El llarg Procés: Cultura i Política a la Catalunya Contemporània (1937-2014). Barcelona: Tusquets. Barceló, Joan. 2014. Contextual effects on subjective national identity. Nations and Nationalism 20: 701-20. [CrossRef]

Barrio, Astrid, and Bonnie N Field. 2018. The push for independence in Catalonia. Nature Human Behaviour 2: 713-15. [CrossRef] [PubMed]

Bel, Germà, Xavier Cuadras-Morató, and Toni Rodon. 2019. Crisis? What crisis? Economic recovery and support for independence in Catalonia. Regional Science Policy and Practice 11: 833-48. [CrossRef]

Borrell, Josep, and Joan Llorach. 2015. Las Cuentas y los Cuentos de la Independencia. Madrid: Catarata.

Bosch, Nuria, and Marta Espasa. 2014. La viabilidad económica de una Cataluña independiente. Revista de Economía Aplicada 22: 135-62.

Bourne, Angela K. 2014. Europeanization and secession: The Cases of Catalonia and Scotland. Journal on Ethnopolitics and Minority Issues in Europe 13: 94-120.

Boylan, Brandon M. 2015. In pursuit of independence: The political economy of Catalonia's secessionist movement. Nations and Nationalism 21: 761-85. [CrossRef]

Cardenal, Juan Pablo. 2020. La telaraña: la Trama Exterior del Procés. Barcelona: Ariel.

Coll, Joaquim, Ignacio Molina, and Manuel Arias-Maldonado, eds. 2018. Anatomía del Procés. Madrid: Debate.

Crameri, Kathryn. 2014. Goodbye Spain? The Question of Independence for Catalonia. Eastbourne: Sussex Academic Press.

Crameri, Kathryn. 2015. Political power and civil counterpower: The complex dynamics of the Catalan independence movement. Nationalism and Ethnic Politics 21: 104-20. [CrossRef]

Cuadras-Morató, Xavier, and Toni Rodon. 2019. The dog that didn't bark: On the effect of the Great Recession on the surge of secessionism. Ethnic and Racial Studies 42: 2189-208. [CrossRef]

Dowling, Andrew. 2018. The Rise of Catalan Independence: Spain's Territorial Crisis. New York: Routdlege.

Elliott, John Huxtable. 2018. Scots and Catalans: Union and Disunion. New Haven: Yale University Press.

Garcia, Luisa. 2018. El Naufragio: La Deconstrucción del Sueño Independentista. Barcelona: Planeta.

Griffiths, Ryan D, Pablo Guillén-Alvarez, and Ferrán Martínez i Coma. 2015. Between the sword and the wall: Spain's limited options for Catalan secessionism. Nations and Nationalism 21: 43-61. [CrossRef]

Guntermann, Eric, André Blais, Ignacio Lago, and Marc Guinjoan. 2018. A study of voting behaviour in an exceptional context: The 2017 Catalan election study. European Political Science. [CrossRef]

Hierro, Jose Maria. 2015. Crafting identities in a multinational context: Evidence from Catalonia. Nations and Nationalism 21: 461-82. [CrossRef]

Lepic, Martin. 2017. Limits to territorial nationalization in election support for an independence-aimed regional nationalism in Catalonia. Political Geography 60: 190-202. [CrossRef]

Llaneras, Kiko. 2017. El Apoyo a la Independencia Tiene Raíces Económicas y de Origen Social. El País. Available online: https://politica.elpais.com/politica/2017/09/28/ratio/1506601198_808440.html (accessed on 13 February 2020).

Maza, Adolfo Jesus, José Villaverde, and María Hierro. 2019. The 2017 Regional Election in Catalonia: An attempt to understand the pro-independence vote. Economia Politica 36: 1-18. [CrossRef]

Miley, Thomas Jeffrey. 2007. Against the thesis of the "civic nation": The case of Catalonia in contemporary Spain. Nationalism and Ethnic Politics 13: 1-37. [CrossRef]

Miley, Thomas Jeffrey. 2013. Blocked articulation and nationalist hegemony in Catalonia. Regional and Federal Studies 23: 7-26. [CrossRef]

Miley, Thomas Jeffrey, and Ricardo Garvía. 2019. Conflict in Catalonia: A sociological approximation. Genealogy 3: 56. [CrossRef]

Minder, Raphael. 2017. The Struggle for Catalonia: Rebel Politics in Spain. London: Hurst and Co.

Morel, Sandrine. 2018. En el huracán catalán. Barcelona: Planeta.

Muñoz, J., and R. Tormos. 2013. El apoyo a la independencia de Cataluña: Identidad o cálculos económicos. Zoom Político 19. [CrossRef]

Muñoz, Jordi, and Raúl Tormos. 2015. Economic expectations and support for secession in Catalonia: Between causality and rationalization. European Political Science Review 7: 315-41. [CrossRef] 
Muro, Diego, and Martijnc C. Vlaskamp. 2016. How do prospects of EU membership influence support for secession? a survey experiment in Catalonia and Scotland. West European Politics 39: 1115-38. [CrossRef]

OEC Group. 2017. La Cataluña Immune al Procés. Barcelona: SCC, April 20. Available online: https://www. societatcivilcatalana.cat/sites/default/files/docs/La-Cataluna-inmune-vf.pdf (accessed on 13 February 2020).

Oller, Josep Maria, Albert Satorra, and Adolf Tobeña. 2019a. Pathways and legacies of the secessionist push in Catalonia: Linguistic frontiers, economic segments and media roles within a divided society. Policy Network Papers. October. Available online: https://policynetwork.org/publications/papers/pathways-and-legacies-ofthe-secessionist-push-in-catalonia/ (accessed on 13 February 2020).

Oller, Josep Maria, Albert Satorra, and Adolf Tobeña. 2019b. Unveiling pathways for the fissure among secessionists and unionists in Catalonia: Identities, family language and media influence. Palgrave Communications 5: 148. [CrossRef]

Piketty, Thomas. 2019. Capital and Ideology. Cambridge: Harvard University Press.

Rodon, Toni, and Marc Guinjoan. 2018. When the context matters: Identity, secession and the spatial dimension in Catalonia. Political Geography 63: 75-87. [CrossRef]

Romero-Vidal, Xavier. 2019. Two temperatures for one thermostat: The evolution of policy attitudes and suport for independence in Catalonia 1991-2018. Nations and Nationalism. [CrossRef]

Sánchez Cartas, Juan Manuel. 2015. Herramientas Económicas y Secesión: Un Enfoque Heurístico Para el Caso Catalán. Master's thesis, Universidad de Alcalá, Alcalá de Henares, Madrid, Spain.

Serrano, Ivan. 2013. Just a matter of identity?: Support for independence in Catalonia. Regional and Federal Studies 23: 523-45. [CrossRef]

Sorens, Jason. 2005. The cross-sectional determinants of secessionism in advanced democracies. Comparative Political Studies 38: 304-26. [CrossRef]

Sorens, Jason. 2008. Regionalists against secession: The political economy of territory in advanced democracies. Nationalism and Ethnic Politics 14: 325-60. [CrossRef]

Tobeña, Adolf. 2017a. La Pasión Secesionista: Psicobiología del Independentismo. Barcelona: EDLibros. (English version The secessionist passion, Madrid: Funambulista-Euromind, 2019).

Tobeña, Adolf. 2017b. Secessionist urges in Catalonia: Media indoctrination and social pressure effects. Psychology 8: 77-96. [CrossRef]

Ucelay-da Cal, Enric. 2018. Breve Historia del Separatismo en Cataluña. Barcelona: Penguin Random House.

(C) 2020 by the authors. Licensee MDPI, Basel, Switzerland. This article is an open access article distributed under the terms and conditions of the Creative Commons Attribution (CC BY) license (http://creativecommons.org/licenses/by/4.0/). 